\title{
EVALUATION OF THE ANTIOXIDANT CAPACITY OF Psoralea glandulosa L. (Fabaceae) EXTRACTS
}

\author{
ALEJANDRO M. MADRID ${ }^{\prime *}$, LUIS J. ESPINOZA ${ }^{1}$, MARCO A. MELLADO', MAURICIO E. OSORIO , \\ IVAN J. MONTENEGRO', CARLOS E. JARA ${ }^{2}$
}

\author{
${ }^{1}$ Departamento de Química, Universidad Técnica Federico Santa María, Av. España $N^{\circ} 1680$, Valparaíso, Chile. \\ ${ }^{2}$ Facultad de Ciencias, Universidad de Valparaíso, Gran Bretaña 1111, Valparaíso, Chile.
}

(Received: May 14, 2012 - Accepted: June 26, 2012)

\begin{abstract}
The antioxidant properties of different extracts of culen (Psoralea glandulosa L., Fabaceae) herb from Gran Valparaíso location in Chile were evaluated. Antioxidant capacity was assessed in four different model systems. Antioxidant models were examined by measuring the scavenging activity of extracts on 2,2-diphenyl-1-pycrylhydrazil $\left(\mathrm{DPPH}^{\bullet}\right)$ as well as on hydrogen peroxide $\left(\mathrm{H}_{2} \mathrm{O}_{2}\right)$, the oxidant species. In addition, extracts were evaluated by ferric reducing antioxidant power (FRAP) and the total peroxyl radical-trapping potential (TRAP). The amount of dried extract, the content of total phenolics, flavonoids and hydrolyzed sugar were also determined. The leaves extracts from culen expressed very strong scavenging activity, reducing the $\mathrm{DPPH}\left(\mathrm{IC}_{50}=1.00 \mathrm{mg} / \mathrm{mL}\right.$ to 1.61 $\mathrm{mg} / \mathrm{mL})$ and neutralizing $\mathrm{H}_{2} \mathrm{O}_{2}\left(\mathrm{IC}_{50}=34.29 \mathrm{mg} / \mathrm{mL}\right.$ to $\left.64.87 \mathrm{mg} / \mathrm{mL}\right)$. Also, dichloromethane extract of the leaves showed notable index of FRAP $(2.71 \mathrm{mM})$ and TRAP $(1.19 \mathrm{mM})$. The results suggest strong antioxidant potential of dichloromethane and ethyl acetate extracts of leaves of $P$. glandulosa that could be partially explained by the levels of phenolics (1.65 mg GAE/g dry extract) and flavonoids (55.34 mg QE/g dry extract) respectively.
\end{abstract}

Keywords: Psoralea glandulosa, Fabaceae, Total phenolics, Flavonoids, Antioxidant capacity, DPPH radical, FRAP, TRAP.

\section{INTRODUCTION}

There is consensus that adequate antioxidant levels maintain a normal function of cells and tissues. Decrease in the levels of these substances can be an origin of a series of pathologies. These diseases, such as malignancies, cardiovascular disorders, diabetes, rheumatism, Alzheimer's disease and ageing processes, are often connected with oxidative stress, reactive oxygen species (ROS) and lipid peroxidation (LP) ${ }^{1,2}$. The evaluation of antioxidants provides useful index of the capacity of the organism to sustain conditions of oxidative stress. The importance of the defenses against deleterious free radical mediated processes has led to great efforts aiming at the development of synthetic antioxidants, such as butylated hydroxyanisole (BHA) and butylated hydroxytoluene (BHT), which are widely used in the food industry. However, animal test have demonstrated that BHA and BHT accumulate in the body and result in liver damage and carcinogenesis ${ }^{3-8}$. Therefore, development and utilization of more effective and non-toxic antioxidants of natural origin compounds present in plant extracts are desired ${ }^{9-12}$. Due to the above there is an increasing interest in the antioxidant effects of compounds derived from herbs that could be relevant in relation to their nutritional incidence effects and their role in health and diseases ${ }^{13}$

Psoralea glandulosa L., popularly known as "culen" or "hualhua", has been used traditionally as medicine in Chile and recommended for the treatment of relieving digestive disorders, especially diarrhea, wound healing and hemorrhoids. It acts as an anthelmintic, soothing, vulnerary, tonic and febrifuge. It is also known as controversial hypoglycemic agent ${ }^{14,15}$. Biological and pharmacological studies for this species both in extracts and in the essential oil from the leaves of Psoralea glandulosa have shown different uses for human health, for example, extracts from petroleum ether and dichloromethane are active against gram positives ${ }^{16}$, antipyretic agents and antiinflamatories ${ }^{17,18}$ On the other hand, the essential oil has shown to be active against Aspergillus nigra, one of the most damaging phytopathogens for plants and vegetables ${ }^{19}$. There are no reports that have led to the antioxidant capacity of $P$. glandulosa L. But we have certainly found some reports on the antioxidant capacity within the genus Psorlaea, especially P. corylifolia.

In the present study, chemical screens of hexane, dichloromethane, ethyl acetate and methanol extracts of Psoralea glandulosa L. were performed. Total phenolics, flavonoids and total hydrolyzed sugar contents were quantified and the antioxidant capacity of the extracts was determined in vitro by the neutralization of 2,2-diphenyl-1-pycrylhydrazil ( $\mathrm{DPPH}^{\bullet}$ ) radical and the oxidant specie hydrogen peroxide $\left(\mathrm{H}_{2} \mathrm{O}_{2}\right)$, as well as by ferric reducing antioxidant power (FRAP) and the total peroxyl radical-trapping potential (TRAP).

\section{EXPERIMENTAL}

\section{Plant material}

In October 2011, Psoralea glandulosa L. was collected in the 33-km route Lo Orozco (F-50), SE of Valparaíso $33^{\circ} \mathrm{S}$ Lat., Chile, and was identified by Forest Engineer Patricio Novoa, Botanical Expert, Horticulture Department Chief, "Jardín Botánico Nacional", Viña del Mar, Chile. Voucher specimen $\mathrm{N}^{\mathrm{o}} 11101-\mathrm{Pg}$ is kept in the Herbarium of the Natural Products Laboratory, "Dr. Herbert Appel A", UTFSM, Valparaíso, Chile.

\section{Extraction Procedure}

The powdered plant material (leaves, stem, bark and root) was subjected to successive extractions taking from non-polar to polar solvents like hexane, dichloromethane, ethyl acetate and methanol for $48 \mathrm{~h}$. at room temperature. All the extracts were concentrated to dryness in a rotary evaporator (temperature $\left.30-35{ }^{\circ} \mathrm{C}\right)$

\section{Determination of total phenolic content}

The amount of total phenolic compounds in extracts was determinated spectrophotometrically using Folin-Ciocalteu $(\mathrm{FC})$ as reagent according to the method used by Waterman ${ }^{20}$ with small modifications Köhler ${ }^{21}$. Each extract sample $(5 \mathrm{mg})$ was diluted to $10 \mathrm{~mL}$ with distilled water and ethanol $(1: 1 \mathrm{v} / \mathrm{v})$. This solution $(0.5 \mathrm{~mL})$ was then mixed with $2.5 \mathrm{~mL}$ of $0.2 \mathrm{~N} \mathrm{FC}$ reagent for 5 min and $2 \mathrm{~mL} 7.5 \%$ sodium carbonate solution was then added. The mixture was incubated in the dark at room temperature for $2 \mathrm{~h}$. The absorbance of the resulting solution was measured at $700 \mathrm{~nm}$ on a UV-Vis spectrophotometer (Jenway 6320D, Bibby Scientific Limited, Beacon Road, Stone, Staffordshire ST15 0SA, UK) using distilled water and ethanol $(1: 1 \mathrm{v} / \mathrm{v})$ as blank. The concentration of total phenolic compounds was expressed in mg gallic acid equivalents (GAE) per g dried extract (d.e.), using a standard curve of gallic acid $(0-200 \mathrm{mg} / \mathrm{L})$ treated the same way as samples. All measurements were replicated three times.

\section{Estimation of total flavonoid content}

The total flavonoid content was determined using the Dowd method as adapted by Arvouet-Grand, Vennat, Pourrat, and Legret ${ }^{22}$. Briefly, $5 \mathrm{~mL}$ of $2 \%$ aluminium trichloride $\left(\mathrm{AlCl}_{3}\right)$ in ethanol was mixed with the same volume of extract solution in ethanol $(1.0 \mathrm{mg} / \mathrm{mL})$. Absorption readings at $415 \mathrm{~nm}$ were taken after 10 min against a blank sample consisting of a $5 \mathrm{~mL}$ extract solution with $5 \mathrm{~mL}$ methanol without $\mathrm{AlCl}_{3}$. The total flavonoid content was determined using a standard curve with quercetin $(0-70 \mathrm{mg} / \mathrm{L})$ as the standard. The mean of three readings was used and expressed as mg of quercetin equivalents $(\mathrm{QE}) /$ per g dry extract.

Estimation of total hydrolyzed sugar content

The total hydrolyzed sugar content was determinated using the method by 
Bruneton $^{23}$ and Domingue $\mathrm{z}^{24}$ with modifications. Briefly, $3 \mathrm{~mL}$ of ethanolics extracts were mixed with $4 \mathrm{~mL} 6 \mathrm{M} \mathrm{HCl}$ and $3 \mathrm{~mL}$ of distilled water. After incubation at room temperature for 4 days, this mixture was extracted with $5 \mathrm{~mL}$ of ethyl acetate, two times, then discard organic layer. The aqueous solution was dilute to $20 \mathrm{~mL}$. Then $1 \mathrm{~mL}$ extract were mixed with $1 \mathrm{~mL} 0.5 \%$ anthrone in ethanol and $5 \mathrm{~mL}$ of concentrate $\mathrm{H}_{2} \mathrm{SO}_{4}$. The mixture was cooled at room temperature for $10 \mathrm{~min}$. The absorbance of the resulting solution was measured at $621 \mathrm{~nm}$ using distilled water as the blank. The total hydrolyzed sugar content was determinated using a standard curve with glucose anhydrous (1 a $140 \mathrm{mg} / \mathrm{L})$ as the standard. The mean of three readings was used and expressed in mg glucose equivalents (GES) per g extract.

\section{Antioxidant capacity}

\section{Reactive Oxygen Species scavenging capacity}

Reactive Oxygen Species (ROS) scavenging capacity of the extracts was evaluated by measuring scavenging activity on $\mathrm{DPPH}^{\bullet}$ and the oxidant specie $\mathrm{H}_{2} \mathrm{O}_{2}$.

\section{DPPH assay}

The DPPH assay was performed as described previously by BrandWilliams ${ }^{25}$ with modifications Neda ${ }^{26} .0 .1 \mathrm{~mL}$ the samples (from 0 to $4 \mathrm{mg} / \mathrm{L}$ of the extracts) were mixed with $2.9 \mathrm{~mL} 50 \mu \mathrm{M} \mathrm{DPPH}{ }^{\bullet}$ solution was freshly prepared in ethanol. $2.9 \mathrm{~mL} 50 \mu \mathrm{M}$ DPPH $^{\bullet}$ solution with $0.1 \mathrm{~mL}$ ethanol was used as a control. The absorbance of the resulting solutions, control and the blank (with the reagents only) were recorded after $15 \mathrm{~min}$ at room temperature. Each sample was replicated three times. The disappearance of $\mathrm{DPPH}^{\bullet}$ was detected spectrophotometrically at $517 \mathrm{~nm}$.

Percent radical scavenging capacity (RSC) was calculated by the following equation:

$\operatorname{RSC}(\%)=100 \% \times\left(\mathrm{A}_{\text {control }}-\mathrm{A}_{\text {sample }}\right) / \mathrm{A}_{\text {control }}$

From the obtained RSC (\%) values the $\mathrm{IC}_{50}$ value, which represent the concentrations of extracts that caused $50 \%$ neutralization, was determined by linear regression analysis.

\section{Hydrogen peroxide scavenging activity}

Scavenging activity on $\mathrm{H}_{2} \mathrm{O}_{2}$ was carried out according to the method of Ruch, Cheng and Klaunig ${ }^{27}$. A solution of $\mathrm{H}_{2} \mathrm{O}_{2}(40 \mathrm{mM})$ was freshly prepared in $0.05 \mathrm{M} \mathrm{KH}_{2} \mathrm{PO}_{4}-\mathrm{K}_{2} \mathrm{HPO}_{4}$ phosphate buffer $(\mathrm{pH}=7.4)$. The samples (from 2.5 to $10 \mu \mathrm{L}$ of the $0.1 \%$ extracts) were mixed with $3.4 \mathrm{ml}$ phosphate buffer and 0.6 $\mathrm{ml} 40 \mathrm{mM} \mathrm{H}_{2} \mathrm{O}_{2}$. The absorbance of the resulting solutions and the blank $(3 \mathrm{~mL}$ phosphate buffer) was detected spectrophotometrically at $230 \mathrm{~nm}$. The percent of $\mathrm{H}_{2} \mathrm{O}_{2}$ neutralization was calculated using the following equation:

$$
\operatorname{RSC}(\%)=100 \% \times\left(\mathrm{A}_{\text {blank }}-\mathrm{A}_{\text {sample }}\right) / \mathrm{A}_{\text {blank }}
$$

From the obtained $\mathrm{RSC}$ values the $\mathrm{IC}_{50}$ value, which represents the concentration of extracts that caused $50 \%$ neutralization, was determined by linear regression analysis.

\section{Ferric Reducing Antioxidant Potential (FRAP) Assay}

The ferric reducing power of plant extracts was measured as described Dudonné $^{28}$ with modifications. This method is based on the reduction, at low $\mathrm{pH}$, of a colorless ferric complex ( $\mathrm{Fe}^{3+}$-tripyridyltriazine) to a bluecolored ferrous complex ( $\mathrm{Fe}^{2+}$-tripyridyltriazine) by the action of electrondonating antioxidants. The reduction is monitored by measuring the change of absorbance at $593 \mathrm{~nm}$. The working FRAP reagent was prepared daily by mixing 10 volumes of $300 \mathrm{mM}$ acetate buffer, $\mathrm{pH} 3.6$, with 1 volume of $10 \mathrm{mM}$ TPTZ (2,4,6-tri(2-pyridyl)-s-triazine) in $40 \mathrm{mM}$ hydrochloric acid and with 1 volume of $20 \mathrm{mM}$ ferric chloride. A standard curve was prepared using various concentrations of Trolox ${ }^{\mathrm{TM}}$. All solutions were used on the day of preparation. One hundred microliters of sample solutions and $300 \mu \mathrm{L}$ of deionized water were added to $3 \mathrm{~mL}$ of freshly prepared FRAP reagent. The reaction mixture was incubated for $30 \mathrm{~min}$ at $37^{\circ} \mathrm{C}$ in a water bath. Then, the absorbance of the samples was measured at $593 \mathrm{~nm}$. A sample blank reading using ethanol was also taken. The difference between sample absorbance and blank absorbance was calculated and used to calculate the FRAP value. In this assay, the reducing capacity of the plant extracts tested was calculated with reference to the reaction signal given by a Trolox ${ }^{\mathrm{TM}}$ solution. FRAP values were expressed as $\mathrm{mM}$ Trolox ${ }^{\mathrm{TM}}$. All measurements were done in triplicate.

\section{Total Reactive Antioxidant Potential (TRAP) assay}

The method developed by Romay ${ }^{29}$ was slightly modified in this experiment. A $10 \mathrm{mM}$ solution of ABAP (2,2'-azo-bis(2-amidino propane) was mixed with $150 \mu \mathrm{M}$ solution of ABTS (2,2'-azinobi(3-ethylbenzothiazoline6-sulfonic acid) in $100 \mathrm{mM}$ solution of PBS (phosphate buffered saline) a $\mathrm{pH}$ 7.4. The mixture was incubated at $45^{\circ} \mathrm{C}$ for $30 \mathrm{~min} .10 \mu \mathrm{L}$ of sample solution was added to $990 \mu \mathrm{L}$ of the resulting blue-green ABTS radical solution. The decrease of absorbance of TRAP solutions and ABTS as blank were recorded after $30 \mathrm{~s}$ at room temperature. Then, the absorbance of the samples was measured at $734 \mathrm{~nm}$. The total antioxidant capacity (TRAP) of extracts was expressed in $\mathrm{mM}$ Trolox ${ }^{\mathrm{TM}}$ equivalents (TEAC), using a standard curve of Trolox $^{\mathrm{TM}}(0-120 \mathrm{mg} / \mathrm{L})$. All measurements were replicated three times.

\section{Statistical analysis}

The data was reported as mean values \pm standard deviation (SD). In the case that the distribution is parametric data, there will be a One-Way ANOVA test, if the distribution corresponds to non-parametric tests. Kruskal-Wallis ANOVA was used with a confidence level of $95 \%$. Values representing the concentrations of investigated extracts that cause $50 \%$ of neutralization or inhibition $\left(\mathrm{IC}_{50}\right)$ were determined by linear regression analysis of RSC (\%), FRAP and TRAP results (STATISTICA 7.0 program).

\section{RESULTS AND DISCUSSION}

\section{Chemical composition}

Air dried and ground plant material (1 $\mathrm{kg}$ of leaves, stem, bark and root) was extracted successively at room temperature with $3 \mathrm{~L}$ for each of the following solvents $n$-hexane (n-Hex), dichloromethane $\left(\mathrm{CH}_{2} \mathrm{Cl}_{2}\right)$, ethyl acetate $(\mathrm{EtOAc})$ and methanol $(\mathrm{MeOH})$. After removing solvents in vacuo; it was obtained certain amount of dry extract from each part of plant parts respectively (Table 1). All extracts were submitted to antioxidant capacity assays. Total phenolics (1.65 mg GAE/g dry extract) and flavonoids (55.34 $\mathrm{mg} \mathrm{QE} / \mathrm{g}$ dry extract) were present in higher concentrations in extracts of leaves instead of the bark of $P$. glandulosa which has the highest amount of sugars (167.49 mg GES/g dry extract) (Table 1). One would expect to find larger amounts of phenolic substances in all parts collected but these were mainly found in the leaves of the Psoralea glandulosa, due to the properties attributed to this plant. In particular, these compounds are concentrated mainly in the leaves. These results could be related to the protective role of phenolics, especially the flavonoid aglycones, which are recurrent in the plants, collected from the roadside and they are located on the outskirts of two towns between Valparaíso and Casablanca, Region de Valparaíso. One of the functions of these biomolecules, which are produced in response to ecological stress factors like pollution and solar radiation, protecting the integrity of biomolecules high physiological interest ${ }^{30}$. In the case of extracts of methanol from bark and root, we have found mainly sugars. This could be explained because sugars are generally carried from leaves to roots, and they are usually absorbed in the form of starch or are simply metabolized by the plant ${ }^{23,31}$. However, plants adapted to stress conditions, have mechanisms to cope with this stress such as increased availability of soluble sugars, greater activity of glycolytic pathway and involvement of antioxidant defense mechanism to cope with the oxidative stress $^{32}$. Besides the sugars are polyhydroxylated substances and therefore latent source of $\mathrm{H}^{\bullet}$ donor, which tends to increase antioxidant capacity. Also, has been reported that DPPH Scavenging activity a significant difference between the free aglycones and glycosides, the latter being those with higher antioxidant capacity ${ }^{33}$.

\section{Antioxidant capacity}

The antioxidant capacity of Psoralea glandulosa extracts was evaluated in a series of in vitro tests. Each of these assays is based in one feature of antioxidant capacity, which is the ability to scavenge or the ability to evaluate the reducing power. Multiple in vitro methods for the evaluation of the antioxidant activities of different plant products are recommended because the composition of plant extracts is complex ${ }^{34,35}$. Thus, the antioxidant properties of the examined Psoralea glandulosa extracts were evaluated as free Radical Scavenging Capacity (RSC) as well as FRAP and TRAP. In the DPPH-test, the ability of examined extracts to act as donors for hydrogen atoms or electrons to reduce DPPH ${ }^{\bullet}$ into DPPH-H was measured spectrophotometrically. Assessed extracts, made from Psoralea glandulosa, were able to reduce the stable radical $\mathrm{DPPH}^{\bullet}$ to the yellow coloured DPPH-H, the experiments confirmed that free radical scavenging activity of all leaves extracts reaching $50 \%$ of reduction with an $\mathrm{IC}_{50}$ of $1.00 \mathrm{mg} / \mathrm{mL}$ to $1.61 \mathrm{mg} / \mathrm{mL}$. The $\mathrm{IC}_{50}$ values (Table 2) for the investigated extracts had a direct correlation with the amount of phenols and flavonoids found in the plant. 
Table 1. Amounts of dried extracts, total phenolics, flavonoids and hydrolyzed sugar ( \pm SD) of Psoralea glandulosa extracts.

\begin{tabular}{|c|c|c|c|c|c|}
\hline $\begin{array}{c}\text { Part of } \\
\text { P. glandulosa }\end{array}$ & Extract & $\begin{array}{c}\text { Dried } \\
\text { extract }(g)\end{array}$ & $\begin{array}{l}\text { Phenolics } \\
\text { (\%GAE) }\end{array}$ & $\begin{array}{l}\text { Flavonoids } \\
(\% Q E)\end{array}$ & $\begin{array}{c}\text { Sugars } \\
(\% \text { GES) }\end{array}$ \\
\hline \multirow{4}{*}{ Leaf } & n-Hex & 20.0002 & $1.31 \pm 0.00$ & $10.92 \pm 0.01$ & $0.00 \pm 0.04$ \\
\hline & $\mathrm{CH}_{2} \mathrm{Cl}_{2}$ & 24.6785 & $1.65 \pm 0.00$ & $37.49 \pm 0.01$ & $0.00 \pm 0.01$ \\
\hline & EtOAc & 18.8976 & $1.05 \pm 0.00$ & $53.31 \pm 0.01$ & $4.28 \pm 0.09$ \\
\hline & $\mathrm{MeOH}$ & 15.7543 & $0.50 \pm 0.00$ & $55.34 \pm 0.02$ & $11.76 \pm 0.05$ \\
\hline \multirow{4}{*}{ Stem } & n-Hex & 9.7931 & $0.45 \pm 0.00$ & $3.35 \pm 0.00$ & $0.00 \pm 0.21$ \\
\hline & $\mathrm{CH}_{2} \mathrm{Cl}_{2}$ & 13.9350 & $0.63 \pm 0.00$ & $24.14 \pm 0.01$ & $0.00 \pm 0.00$ \\
\hline & EtOAc & 17.2691 & $0.80 \pm 0.00$ & $22.87 \pm 0.01$ & $8.89 \pm 0.48$ \\
\hline & $\mathrm{MeOH}$ & 11.8756 & $0.41 \pm 0.00$ & $11.71 \pm 0.00$ & $32.34 \pm 0.88$ \\
\hline \multirow{4}{*}{ Bark } & n-Hex & 5.0974 & $0.21 \pm 0.00$ & $5.02 \pm 0.00$ & $1.51 \pm 0.04$ \\
\hline & $\mathrm{CH}_{2} \mathrm{Cl}_{2}$ & 11.9183 & $0.77 \pm 0.00$ & $17.41 \pm 0.01$ & $0.00 \pm 0.01$ \\
\hline & EtOAc & 13.7869 & $0.89 \pm 0.00$ & $21.55 \pm 0.01$ & $1.65 \pm 0.05$ \\
\hline & $\mathrm{MeOH}$ & 12.4797 & $0.92 \pm 0.00$ & $10.72 \pm 0.00$ & $50.25 \pm 6.35$ \\
\hline \multirow{4}{*}{ Root } & n-Hex & 7.6759 & $0.28 \pm 0.00$ & $1.20 \pm 0.00$ & $0.00 \pm 0.04$ \\
\hline & $\mathrm{CH}_{2} \mathrm{Cl}_{2}$ & 12.0078 & $0.46 \pm 0.00$ & $6.89 \pm 0.01$ & $0.00 \pm 0.07$ \\
\hline & EtOAc & 4.8557 & $0.56 \pm 0.00$ & $10.96 \pm 0.00$ & $0.00 \pm 0.04$ \\
\hline & $\mathrm{MeOH}$ & 12.8916 & $0.82 \pm 0.00$ & $16.06 \pm 0.01$ & $35.99 \pm 3.31$ \\
\hline
\end{tabular}

In addition to other information relevant to antioxidant capacity obtained in the literature, studies on the extracts from the leaves of Psoralea glandulosa have only been conducted, and the following secondary metabolites have been isolated: furocoumarins angelicin and psoralen, along with the meroterpene bakuchiol and derivates ${ }^{16}$. Angelicin and psoralen that are found in a lower percentage in the leaves of the $P$. glandulosa have been reported to possess antibacterial and phototherapeutic activities (psoriasis, eczema, vitiligo, and cutaneous lymphoma) ${ }^{36-38}$. Moreover, bakuchiol is abundant in the leaves of $P$. glandulosa which has been reported to possess DNA polymerase inhibitory activity, antitumor, antifungal, cytotoxic and antioxidant activities ${ }^{39-42}$. The presence of these compounds contributed to the high scavenging power of the extracts of the leaves from culen.

On the other hand hydrogen peroxide is not a free-radical species, it is the source of the very toxic hydroxyl radical, especially in the presence of metal ions like copper or iron. Also, $\mathrm{H}_{2} \mathrm{O}_{2}$ may cross membranes and may slowly oxidise a number of cell compounds. Thus, the elimination of hydrogen peroxide is important for both human health and the protection of pharmaceutical and food systems. The neutralization of $\mathrm{H}_{2} \mathrm{O}$, by the examined extracts was measured spectrophotometrically (Table 2). The ability of the assessed extracts to neutralize $\mathrm{H}_{2} \mathrm{O}_{2}$ was dose dependent, with a higher activity of extracts of the leaves of culen, reaching $\mathrm{IC}_{50}$ values of 34.29 and $36.56 \mathrm{mg} /$ $\mathrm{mL}$ for dichloromethane and ethyl acetate extracts, respectively.

Table 2. $\mathrm{IC}_{50} \mathrm{DPPH}^{\bullet}$ and $\mathrm{H}_{2} \mathrm{O}_{2}$ values of Psoralea glandulosa extracts.

\begin{tabular}{|c|c|c|c|}
\hline $\begin{array}{c}\text { Part of } \\
\text { P. glandulosa }\end{array}$ & Extract & $\begin{array}{c}\mathrm{IC}_{50} \mathrm{DPPH}^{\circ} \\
(\mathrm{mg} / \mathrm{mL})\end{array}$ & $\begin{array}{r}\mathrm{IC}_{50} \mathrm{H}_{2} \mathrm{O}_{2} \\
(\mathrm{mg} / \mathrm{mL})\end{array}$ \\
\hline \multirow{4}{*}{ Leaf } & n-Hex & $1.61 \pm 0.01$ & $45.10 \pm 0.01$ \\
\hline & $\mathrm{CH}_{2} \mathrm{Cl}_{2}$ & $1.00 \pm 0.04$ & $34.29 \pm 0.02$ \\
\hline & EtOAc & $1.04 \pm 0.04$ & $36.56 \pm 0.01$ \\
\hline & $\mathrm{MeOH}$ & $1.07 \pm 0.03$ & $64.87 \pm 0.04$ \\
\hline \multirow{4}{*}{ Stem } & n-Hex & $8.60 \pm 0.38$ & $99.53 \pm 0.01$ \\
\hline & $\mathrm{CH}_{2} \mathrm{Cl}_{2}$ & $2.06 \pm 0.05$ & $507.50 \pm 0,01$ \\
\hline & EtOAc & $1.54 \pm 0.05$ & $571.75 \pm 0.30$ \\
\hline & $\mathrm{MeOH}$ & $5.87 \pm 0.24$ & $292.75 \pm 0.03$ \\
\hline \multirow{4}{*}{ Bark } & n-Hex & $15.21 \pm 1.39$ & $54.86 \pm 0.01$ \\
\hline & $\mathrm{CH}_{2} \mathrm{Cl}_{2}$ & $3.79 \pm 0.11$ & $71.07 \pm 0.01$ \\
\hline & EtOAc & $2.43 \pm 0.14$ & $77.43 \pm 0.01$ \\
\hline & $\mathrm{MeOH}$ & $3.77 \pm 0.09$ & $299.99 \pm 0.01$ \\
\hline \multirow{4}{*}{ Root } & n-Hex & $16.28 \pm 0.21$ & $49.37 \pm 0.03$ \\
\hline & $\mathrm{CH}_{2} \mathrm{Cl}_{2}$ & $3.98 \pm 0.03$ & $63.96 \pm 0.01$ \\
\hline & EtOAc & $2.16 \pm 0.04$ & $69.69 \pm 0.01$ \\
\hline & $\mathrm{MeOH}$ & $2.24 \pm 0.05$ & $269.99 \pm 0.01$ \\
\hline
\end{tabular}

The Total Antioxidant Capacity (TAC) of extracts from different parts of the culen (leaf, stem, bark and root) was evaluated using two different assays. TAC values of the extracts for each assay are shown in Table 3. In examining results of the FRAP assays, dichloromethane extract of leaves had the largest antioxidant capacity, followed by hexane extract of the leaves, whereas methanolic extracts of stem and bark exhibited the lowest FRAP values for the TRAP assays, respectively. The high antioxidant capacity of the dichloromethane extract of leaves is due to the large amount of free phenols and flavonoids.

Also, the hydrolyzed sugar, the relationship between the amount of these compounds and the polarity of the solvent extraction shows that there are significant differences $(p=0.00)$, indicating that methanol extracts are those with the highest concentration of such metabolites. However, performing the same comparison culen parts can be seen with no significant differences ( $p$ $=0.37$ ), indicating that these structures are distributed equally in the plant. The correlations between antioxidant activities and the amount of metabolites present in each of the organs can be seen, in general, as a dependence of phenolic compounds and flavonoids on the activities measured.

Table 3. FRAP and TRAP of Psoralea glandulosa extracts.

\begin{tabular}{|c|c|c|c|}
\hline $\begin{array}{c}\text { Part of } \\
\text { P. glandulosa }\end{array}$ & Extract & $\begin{array}{c}\text { FRAP } \\
\text { (mM Trolox TM) }\end{array}$ & $\begin{array}{c}\text { TRAP } \\
\text { (mM Trolox TM) }\end{array}$ \\
\hline \multirow{4}{*}{ Leaf } & $\mathrm{n}-\mathrm{Hex}$ & $0.93 \pm 0.01$ & $1.18 \pm 0.00$ \\
\cline { 2 - 4 } & $\mathrm{CH}_{2} \mathrm{Cl}_{2}$ & $2.71 \pm 0.01$ & $1.19 \pm 0.00$ \\
\cline { 2 - 4 } & $\mathrm{EtOAc}$ & $0.58 \pm 0.00$ & $1.12 \pm 0.00$ \\
\cline { 2 - 4 } & $\mathrm{MeOH}$ & $0.36 \pm 0.01$ & $0.70 \pm 0.02$ \\
\hline \multirow{4}{*}{ Stem } & $\mathrm{n}-\mathrm{Hex}$ & $0.29 \pm 0.00$ & $0.49 \pm 0.02$ \\
\cline { 2 - 4 } & $\mathrm{CH}_{2} \mathrm{Cl}_{2}$ & $0.46 \pm 0.00$ & $0.68 \pm 0.01$ \\
\cline { 2 - 4 } & $\mathrm{EtOAc}_{4}$ & $0.45 \pm 0.01$ & $0.66 \pm 0.01$ \\
\cline { 2 - 4 } & $\mathrm{MeOH}$ & $0.21 \pm 0.00$ & $0.35 \pm 0.01$ \\
\hline \multirow{4}{*}{ Bark } & $\mathrm{n}-\mathrm{Hex}$ & $0.12 \pm 0.00$ & $0.33 \pm 0.01$ \\
\cline { 2 - 4 } & $\mathrm{CH}_{2} \mathrm{Cl}$ & $0.38 \pm 0.02$ & $0.59 \pm 0.01$ \\
\cline { 2 - 4 } & $\mathrm{EtOAc}_{4}$ & $0.44 \pm 0.01$ & $0.55 \pm 0.01$ \\
\cline { 2 - 4 } & $\mathrm{MeOH}$ & $0.27 \pm 0.00$ & $0.15 \pm 0.02$ \\
\hline \multirow{4}{*}{ Root } & $\mathrm{n}-\mathrm{Hex}$ & $0.09 \pm 0.00$ & $0.41 \pm 0.02$ \\
\cline { 2 - 4 } & $\mathrm{CH}{ }_{2} \mathrm{Cl}$ & $0.26 \pm 0.01$ & $0.54 \pm 0.00$ \\
\cline { 2 - 4 } & $\mathrm{EtOAc}$ & $0.32 \pm 0.01$ & $0.62 \pm 0.01$ \\
\cline { 2 - 4 } & $\mathrm{MeOH}$ & $0.25 \pm 0.01$ & $0.64 \pm 0.01$ \\
\hline
\end{tabular}

For the DPPH activity, in all the organs there is a correlation between flavonoids and $\mathrm{DPPH} \bullet \mathrm{RSC}$ (between $\mathrm{R}^{2}=0.733$ and 0.982 ), so this activity depends on the concentration of flavonoids (Table 4).

In the case of the scavenging activity on $\mathrm{H}_{2} \mathrm{O}_{2}$, there are phenolic 
compounds in leaves and root $\left(\mathrm{R}^{2}=0.738\right.$ and 0.804 , respectively), but in the bark and the stem, the correlation is very low; this may be because in these parts a big amount of sugars is present into the activity quenching (Table 4).

The FRAP activity, in the leaves, stem and bark, possesses a dependency of the presence of phenolic compounds with the activity $\left(\mathrm{R}^{2}=0.713,0.796\right.$ and 0.654 , respectively). Moreover, in the root of the culen, there is a slight dependence on the amount of flavonoids $\left(\mathrm{R}^{2}=0.519\right)$ (Table 4). This may be due to a flow through the plant metabolites, which may be subject to transformation into other phenolic compounds.
Also, TRAP activity, in the leaves, stem and root, possesses a dependency of the presence of phenolic compounds with the activity $\left(\mathrm{R}^{2}=0.835,0.745\right.$ and 0.812 , respectively) (Table 4). Though, in the bark of culen, there is a dependency between TRAP activity with the presence of flavonoids and hydrolyzed sugar, in a low proportion $\left(\mathrm{R}^{2}=0.519\right.$ and 0.680 , respectively). This peculiarity may be because, in general, the outer tissues (such as bark and wood tissue), have a low concentration of phenolic compounds (2.79 mg GAE per g extract) and flavonoids (54.7 mg QE per g extract), while rich in other metabolites such as lignans and lignins $\mathrm{s}^{23,43}$.

Table 4: $\mathrm{R}^{2}$ values for the correlation of data between trials and amount of antioxidant metabolites.

\begin{tabular}{|c|c|c|c|c|c|}
\hline $\begin{array}{c}\text { Part of } \\
\text { P. } g \text { landulos } \boldsymbol{a}\end{array}$ & Metabolites & DPPH & $\mathbf{H}_{\mathbf{2}} \mathbf{O}_{\mathbf{2}}$ & FRAP & TRAP \\
\hline \multirow{3}{*}{ Leaf } & Phenols & 0.023 & 0.738 & 0.713 & 0.835 \\
\cline { 2 - 6 } & Flavonoids & 0.766 & 0.064 & 0.068 & 0.355 \\
\cline { 2 - 6 } & Sugar & 0.149 & 0.699 & 0.425 & 0.932 \\
\hline \multirow{3}{*}{ Stem } & Phenols & 0.731 & 0.017 & 0.796 & 0.745 \\
\cline { 2 - 6 } & Flavonoids & 0.982 & 0.191 & 0.667 & 0.552 \\
\cline { 2 - 6 } & Sugars & 0.013 & 0.001 & 0.435 & 0.544 \\
\hline \multirow{3}{*}{ Root } & Phenols & 0.953 & 0.269 & 0.654 & 0.011 \\
\cline { 2 - 6 } & Flavonoids & 0.693 & 0.036 & 0.978 & 0.519 \\
\cline { 2 - 6 } & Sugars & 0.072 & 0.977 & 0.07 & 0.68 \\
\cline { 2 - 6 } & Phenols & 0.625 & 0.804 & 0.383 & 0.812 \\
\cline { 2 - 6 } & Flavonoids & 0.733 & 0.673 & 0.519 & 0.908 \\
\hline
\end{tabular}

On the other hand, the comparison studies done with nutraceutical antioxidants indicated that dichloromethane extract of the leaves exhibited maximum DPPH radical scavenging activity at lesser concentration than BHT and BHA respectively (Table 5).

Table 5: DPPH radical scavenging effect of dichloromethane extract of leaves of Psoralea glandulosa vs commercial control.

\begin{tabular}{|c|c|}
\hline Antioxidant & $\mathbf{I C}_{\mathbf{5 0}} \mathbf{D P P H} \mathbf{~} \mathbf{~}^{\mathbf{m g} / \mathbf{m L})}$ \\
\hline $\mathrm{CH}_{2} \mathrm{Cl}_{2}$ Extract of the leaves & $1.00 \pm 0.04$ \\
\hline BHT & $3.10 \pm 0.01$ \\
\hline BHA & $2.89 \pm 0.02$ \\
\hline
\end{tabular}

Finally, Psoralea glandulosa present a similar composition of their leaves and values of DPPH in studies performed on its related species as Psoralea corylifolia, a tree native to China ${ }^{44,45}$.

\section{CONCLUSIONS}

The measurement of antioxidant capacity was used as a method for the evaluation of culen extracts. The comparison of antioxidant activities $\left(\mathrm{IC}_{50}\right.$ values) of the investigated extracts (Table 2) showed variable effects that depended on examined extracts and the models used for evaluation. Based, on the distribution of metabolites quantified in each of the parts, it can be seen that the values obtained in the leaves of the plant are having a higher antioxidant capacity, particularly those belonging to dichloromethane and the ethyl acetate extracts which provide with higher concentrations of phenolic compounds and flavonoids, considering the tests performed. These preliminary studies are highly interesting as they open new pathways for further studies in antioxidant capacity, which would allow the validation of the traditional use of plants in the treatment of infections and diabetes.

\section{ACKNOWLEDGEMENTS}

The authors thank Centro Científico Tecnológico de Valparaíso (CCTVal, Proyecto BASAL FB/08/21, int. cod. FB/30LE/10), PAC 2010-2012 for A. M., PAC 2009-2012 for M.O., DGIP of Universidad Técnica Federico Santa María for financing, support to this research and Granja Apícola Metamorfosis.

\section{REFERENCES}

1. L. P. Van de Vijver, A. F. Kardinaal, D. E. Grobbe, H. M. Princen, G. Van Poppel, Prostag. Leukotr. Ess. 57, 479, (1997)

2. M. A. Smith, G. Perry, W. A. Pryor, Free Radic. Biol. Med. 32, 1049, (2002)

3. B. M. Ames, Science 221, 1256, (1983)

4. P. Baardseth, Food Addit. Contam. 6, 201, (1989)

5. H. C. Grice, Food Chem. Toxicol. 24, 1127, (1986)

6. N. Ito, S. Fukushima, A. Hasegawa, M. Shibata, and T. Ogiso, J. Natl. Cancer Inst. 70, 343, (1983)

7. N. Ito, M. Hirose, S. Fukushima, H. Tsuda, T. Shirai, Food Chem. Toxicol. 24, 1099, (1986)

8. H. P. Wichi, Food Chem. Toxicol. 26, 717, (1988)

9. M. Namiki, Crit. Rev. Food Sci. 29, 273, (1990)

10. G. Jiangning, W. Xinchu, W. Hou, L. Qinghua, B. Kaishun, Food Chem. 91, 287, (2005)

11. S. Oliveira, F. Dal-pizzol, J. Moreira, P. Schenkel, G. Gosmann, Acta Farm. Bonaerense 23, 365, (2004)

12. T. Shahzadi, M. Abbasi, T. Riaz, A. U. Rehman, S. Siddiqui and M. Ajaib, J. Chil. Chem. Soc. 56, 678, (2011)

13. I, Zampini, M. I. Isla and G. Schmeda, J. Chil. Chem. Soc. 54, 477, (2009)

14. A. Hoffmann, C. Farga, J. Lastra and E. Veghazi in The Plantas Medicinales de uso común en Chile, eds. Fundación Claudio Gay, Santiago, 1992; pp. 79-82.

15. S. Rozzi in The Las Plantas. Fuente de Salud, eds. Pía Sociedad de San Pablo, Santiago, 1984; pp. 104.

16. S. Erazo, R. García, F. and Delle monache, Rev. Latinoam. Quim. 21, 62, (1990)

17. N. Backhouse, C. Delporte, R. Negrete, P. Salinas, A. Pinto, S. Aravena, B. Cassels, Int. J. Pharmacog. 34, 53, (1996)

18. N. Backhouse, C. Delporte, R. Negrete, S. Erazo, A. Zuñiga, A. Pinto, and B. Cassels, J. Ethnopharmacol. 78, 27, (2001)

19. J. Becerra, M. Bittner, V. Hernández, C. Brintrup, M. Silva, BLACPMA 9, 212, (2010)

20. P. Waterman, S. Mole Analysis of Phenolic plant metabolites, Blacwell Scientific University, Malaysia, 1994.

21. H. Köhler, R. Contreras, G. Zúñiga, Biol. Res. 40, 124, (2007)

22. A. Meda, C. Lamien, M. Romito, J. Millogo, O. Nacoulma, Food Chem. 91, 571, (2010)

23. J. Bruneton Farmacognogsia. Fitoquímica y plantas medicinales, Acribia, España, 2001. 
24. X. Domínguez Métodos de investigación fitoquímica, Limusa S.A., España, 1973.

25. W. Brand-Williams, M. Cuvelier, C. Berset, Lebensm Wiss u Technol. 28, 25, (1995)

26. S.L. Neda, I. Jelena, B. Biljana, Cent. Eur. J. Biol. 5, 331, (2010)

27. R.J. Ruch, S.J. Cheng, J.E. Klaunig, Carcinogenesis 10, 1003, (1989)

28. S. Dudonné, X. Vitrac, P. Coutière, M. Woillez and J.M. Mérillon, J. Agric. Food Chem. 57, 1768, (2009)

29. C. Romay, C. Pascual, E.A. Lissi, Braz. J. Med. Biol Res. 29, 175, (1996)

30. A. Kootstra, Plant Mol. Biol. 26, 771, (1994)

31. T. T. Berezov, B.F. Korovkin Chemistry and metabolism of carbohydrates. Biochemistry, Mir Publishers, Moscow, 1992.

32. Y. H. Chu, C. L. Chang, H. F. Hsu, J. Sci. Food Agric. 80, 561, (2000)

33. R. K. Sairam, D. Kumutha, K. Ezhilmathi, P. S. Deshmukh and G. C. Srivastava, Biol. Plantarum 52, 401, (2008)

34. C. Hu, Y. Yuan, D. Kitts, Food Chem. Toxicol. 45, 2219 (2007)

35. A. M. Nuutila, R. Puupponen-Pimia, M. Aarni, Food Chem. 81, 485, (2003)
36. Y. H. Chu, C. L. Chang, H. F. Hsu, J. Sci. Food Agric. 80, 561, (2000)

37. N. A. Khatune, M. E.Islam, M. E. Haque, P. Khondkar, and M. M. Rahman, Fitoterapia 75, 228, (2004)

38. K. Momtaz, and T. Fitzpatrick, Dermatol. Clin. 16, 227 (1998)

39. P. Autier, J. Dore, and J. Cesarini, Ann. Oncol. 8, 435, (1997)

40. P. G. Latha and K. R. Panikkar, J. Ethnopharmacol. 68, 295, (1999)

41. S. Adhikari, R. Joshi, B. Patro, T. K. Ghanty, G. J. Chintalwar, A. Sharma, S. Chattopadhyay, and T. Mukherjee, Chem. Res. Toxicol. 16, 1062, (2003)

42. K. Lau, L. Fu, C. Wong, Y. Wong, C. Lau, S. Han, P. Chan, P. Fung, C. Lau, M. Huiy, and P. Leung, Am. J. Chinese. Med. 38, 1005 (2010)

43. J. Mann Secondary Metabolism, Oxford University Press, New York, 1980.

44. S. Lim, T. Ha, S. Kim, J. Ahn, H. Park and S. Kim, Brit. J. Nutr. 101, 1031, (2009)

45. B. Kiran and K.A. Raveesha, World Appl. Sci. J. 8, 985, (2010) 